OPEN ACCESS

Edited by:

Ademola Braimoh

World Bank Group, United States

Reviewed by:

Cyrille Rigolot,

Institut National de recherche pour

l'agriculture, l'alimentation et

l'environnement (INRAE), France

Adel M. Naga,

Animal Production Research Institute (APRI), Egypt

*Correspondence:

Véronique Alary

veronique.alary@cirad.fr

Specialty section:

This article was submitted to Land, Livelihoods and Food Security,

a section of the journal

Frontiers in Sustainable Food Systems

Received: 11 June 2021 Accepted: 17 December 2021

Published: 25 January 2022

Citation:

Alary V, Caulfield ME, Amsidder L, Juanes $X$, Boujenane I, Sraïr MT, Sam A, Hammond $J$ and Van Wijk M (2022) Heterogeneity of Resilience of Livelihood Strategies in Pastoral and Agropastoral Farming Systems of

Rural Semi-arid to Arid Areas in

Morocco.

Front. Sustain. Food Syst. 5:723994. doi: 10.3389/fsufs. 2021.723994

\section{Heterogeneity of Resilience of Livelihood Strategies in Pastoral and Agropastoral Farming Systems of Rural Semi-arid to Arid Areas in Morocco}

\author{
Véronique Alary ${ }^{1,2 *}$, Mark E. Caulfield ${ }^{3}$, Lina Amsidder ${ }^{1,4}$, Xavier Juanes ${ }^{1,4}$, \\ Ismaïl Boujenane ${ }^{5}$, Taher M. Sraïri ${ }^{5}$, Adams Sam ${ }^{6}$, James Hammond ${ }^{6}$ and Mark Van Wijk ${ }^{6}$ \\ ${ }^{1}$ Research Unit of Mediterranean and Tropical Livestock Systems (SELMET), MUSE Univ Montpellier, French Agricultural \\ Research Centre for International Development (CIRAD), National Research Institute for Agriculture, Food and the \\ Environment (INRAE), Montpellier SupAgro, Montpellier, France, ${ }^{2}$ French Agricultural Research Centre for International \\ Development (CIRAD), International Center of Agricultural Research in the Dry Areas (ICARDA), Tunis, Tunisia, ${ }^{3}$ Farming \\ Systems Ecology and Rural Livelihoods, Rabat, Morocco, ${ }^{4}$ French Agricultural Research Centre for International \\ Development (CIRAD), Research Unit of Mediterranean and Tropical Livestock Systems (SELMET), Montpellier, France, \\ ${ }^{5}$ Department of Animal Production and Biotechnology, Hassan II Agronomy and Veterinary Medicine Institute, Rabat, \\ Morocco, ${ }^{6}$ International Livestock Research Institute (ILRI), Nairobi, Kenya
}

A large proportion of rural households, particularly in the dry land areas, representative for more than $10 \%$ of the world's land surface and up to $80 \%$ in Morocco, depend for their livelihoods on livestock. They exploit livestock's capacity to live in very harsh environments using herd-mobility at multiple scale level. Understanding the multiple contributions of livestock to the household and national economy raises complex research issues and challenges linked with the multitude of goods and services derived from livestock, their interactions with other family activities, and the local and national context. The objective of our research was therefore to analyse the diversity and assess the resilience of livelihood strategies of farming households oriented to livestock using a set of data collected in the dry land areas (oases and mountainous zones) of Morocco and discuss the livelihood outcome indicators. To achieve this, we have realized a cross-sectional analysis of livelihoods and adaptive capacity, to select a set of pertinent indicators. These indicators have been developed using an adapted version of the Rural Household MultiIndicator Survey (RHoMIS) toolkit for pastoral and agropastoral household systems. Our results highlight the critical importance of livelihood diversification (off-farm diversification, livestock diversification, and crop diversification) in building household resilience and the livelihood outcomes. While livelihood strategies undoubtedly contribute to livelihood outcomes, there is also a critical iterative process, i.e., livelihood outcomes also influence the livelihood strategies at the farming households. The present work proposes an aggregated indicator of livelihood outcomes allowing us to capture the heterogeneity of living conditions of agropastoral systems by considering the main drivers of this system, 
i.e., mobility, livestock species, and physiological stage composition of the herd. This approach could constitute a valuable contribution to help fill the knowledge gaps that do not allow policy makers in developing contextualized rural development policies and instruments in these very harsh environments.

Keywords: resilience profile, livelihood strategies, agropastoral system, RHoMls, capacity of actions, multiindicators approach, Morocco

\section{INTRODUCTION}

The concept of resilience has grown in importance extending from addressing the ability of groups or communities to cope with external stresses (Adger, 2000) but also the capacity to "bouncing forward" [as described by Davoudi et al. (2012)], up to understanding, managing, and governing complex integrated systems of people and nature [see the works of the Stockholm Resilience Center, such as Janssen and Ostrom (2006) or Folke (2016)]. In this resilience thinking, the main challenge is to capture the dynamics and capacity to survive (adaptability) and evolve (transformability) under contexts of local governance (Meuwissen et al., 2019). During the last decade, this concept has come to form a key entry-point to assess the sustainability of systems, i.e., the dynamics and ability to endure in an environment that is changing like in the drylands (e.g., Haddad et al., 2021). Nowadays, we can distinguish two main streams around this approach of sustainability based on resilience. In the first stream, applied at the local level, the assessment of resilience essentially requires an understanding of the stocks and diversity of assets in terms of complementarities and the ability to innovate, change or adapt. This approach has been formalized within the well-known "Sustainable Livelihood Framework," providing a set of quantitative and qualitative indicators that ranged from resource endowment to resource use and passing through the means and rights of access to these resources. Applied to dryland systems, this framework was mainly based on access to current and potential resources ("entitlement") of individuals estimated from the assets and their production, and reciprocal arrangements (share capital, rights, and obligations, also called claims) (Scoones, 2009; Li et al., 2017). Overall, these indicators attempted to encompass a loss of security, affecting the level of well-being at the individual or local level. In the second stream, the research focuses on the nature of capacities, i.e., buffers, adaptive or transformative, to capture the overall ability of the studied system to resist, adapt or reorganize in the face of a set of perturbations (See Berkes et al., 2003; Walker et al., 2004; Darnhofer et al., 2010; Folke et al., 2010; Darnhofer, 2014). This approach shows the interactions, complementarities, or substitutions between the farm and off-farm activities by focusing on the diversity of capacities. Here, resilience is viewed as a process more than as an outcome in facing perturbances.

The resilience thinking applied to pastoral and agropastoral systems has led to a multiplicity of recent research on adaptive capacity and adaptation allowed by livestock and range management' decision making (Leach et al., 2007; Adger et al., 2009; O'Brien and Wolf, 2010; Eakin et al., 2014; Vermeulen et al.,
2018). Notably, Vermeulen et al. (2018) highlighted a set of case studies demonstrating the potential roles of livestock through its multiple functions on the adaptive and transformative capacities of the (agro) pastoral systems. In reference to socio-ecological approaches, the resilience concept has also received significant interest over the past decade, considering the complexity of ecosystems and their inter-relationships with social networks (McAllister et al., 2006; Linstädter et al., 2016). Nevertheless, many research challenges remain with regard to understanding and assessing the adaptive capacity and therefore resilience of farming households who live off livestock income in dryland areas. Some authors such as Abebe (2020) or Melketo et al. (2021) emphasized the effect of location specific factors in determining resilience of family systems based on livestock activity. The multiple roles that livestock play in livelihood strategies and outcomes (e.g., safety capital and productive asset) and the role of complementary activities such as crop cultivation or off-farm activities, still remain important aspects that would benefit from further investigation (Alary et al., 2011).

Moreover, one common measure of the livelihood outcome at national and international level is the Progress out of Poverty

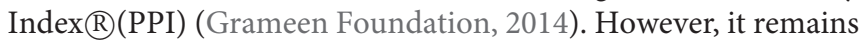
to be seen how appropriate this poverty index, based on 10 indicators related to living conditions (such as type of house, rooms number, family size, etc), is for pastoral and agropastoral family systems based on mobile living conditions. McPeak et al. (2011) proposed a livelihood measure derived from data on cash income from livestock activity with the earnings resulting from direct and indirect gifts and transfers due to social activities around livestock. Here we propose to build a livelihood measure based on herders' perception that we will compare to the PPI index.

The objective of our research was therefore to analyse the diversity and assess the resilience of livelihood strategies of farming households oriented to livestock using a set of data collected in the dryland areas of the oases and mountains of Morocco. To achieve this, we adopted the core modules of the RHoMIS toolkit (see Hammond et al., 2017) of which we added a specific module related to herd management in association with herd-mobility and herd contribution to family livelihood in terms of food security, cash flow or net safety. This new submodule aimed to adapt the current RHoMIS survey toolkit to (agro) pastoral systems. Furthermore, we adopted the conceptual framework of sustainable rural livelihoods that facilitates the analysis of challenges related to rural development, poverty reduction, and environmental management in rural contexts (Scoones, 1998, 2009). Working at the farm and household 
level, we used multiple correspondence analyses (MCA) on household asset variables and variables related to livelihood diversification and social management to develop a set of rural livelihood strategy types. We then characterized and compared resilience profiles with livelihood outcomes among these types by developing a set of resilience components based on formal and informal interviews with village elders and key local stakeholders. We proposed two approaches for livelihood outcomes, one based on PPI and the second on the criteria of living conditions used by the studied communities.

The adaptive capacities were assessed not only through the diversity of capital assets but also in regard to herd-mobility management, social transfers and gender involvement at the household level. The herd-mobility management was considered as both an outcome of social capital and indicator of the pressure on the resource at farm and territory scales. The social transfers included the majority of the loans or gifts given and received at the household level although the gender involvement in (agro) pastoral systems covered the domain of the decision and task management at the household level by identifying the women and young' control on different herd management activities. The mobility of pastoralists exploiting the animal feed resources along different ecological zones is usually considered as a flexible response to a dry and increasingly variable environment (FAO, 2018). We will analyse data from two contrasting dryland regions in Morocco. By better understanding the current pastoral and agropastoral systems in these regions as well as their resilience, we aim to help identify different pathways for future development of mobile livestock activities, an activity that is considered to be a significant opportunity in the face of growing sustainability risks in the region.

\section{MATERIALS AND METHODS Description of Study Areas}

To cover a diversity of pastoral and agropastoral conditions, we selected two contrasting case studies in Morocco, based respectively on camel farming systems in the desert zones in southern Morocco (region Guelmin-Oued Noun), and on sheep and goat systems in the mountainous regions at the margins of an oasis region (Dadès valley, Tinghir province). In these two study areas, the farm and household systems are organized around livestock systems based on mobility. It is notable that in both regions, there is an increasing trend toward livelihood diversification to off-farm and agricultural activities associated with children's education and the aspirations of the young generation. Figure 1 presents the two study areas that were selected to reflect the agroecological diversity in pastoral systems in rural Morocco.

Historically, Guelmim-Oued Noun region was an important location along the trading area for the collection, redistribution, and transit of goods between the south and the north of the Sahara (Attou and Belkadi, 2014). Since the 1950s, camel production has recorded an important period of decline, closely associated with political and social reconfigurations of the country, agricultural modernization in the desert oases (Lazarev and Kadi, 2012), and successive conflicts (Martin, 2011). In 1956, there were an estimated 250,000 camel heads in the region of Guelmim-Oued Noun, declining to 100,000 in the 1970s, and then to less than 50,000 in the 1980s. With regional governmental support in the 2000s and the Green Morocco Plan in 2008, the camel sector has been earmarked as an essential agricultural sector in the South. In 2013, the camel population was estimated at around 200,000 heads (Mahdi, 2015). Surveys took place in and around Guelmim city and the rural community of Tuflit, located $25 \mathrm{~km}$ east of Guelmim city, Guelmim province. Its central position and links with the regional weekly market of Amhirich in Guelmim city for live animals is an important feature of this community (see map 1). Guelmim-Oued Noun's region comprises 4 provinces: Sidi Ifni, Assa Zag, Guelmim, and Tan Tan. With the exception of the province of Sidi Ifni, due to its mountainous relief oriented to the ocean, the provinces are characterized by an arid, Saharan climate with dry, hot summers and cold winters. The region's geomorphology is dominated by mountainous areas (corresponding to the prolongation of the Anti-Atlas from north to northeast) and semi-desertic areas with plains. The average annual rainfall is between $40 \mathrm{~mm}$ in Assa Zag to $120 \mathrm{~mm}$ in Guelmin province. Across the governorate, agriculture accounts for only $3.3 \%$ of the total land area, compared to $51.4 \%$ for pastureland and $40.8 \%$ for wastelands. The remaining land-use is mainly forest. This explains the predominant presence of camels, sheep and goats in this environment.

The second study area is located in the province of Tinghir at the intersection between the desert zones and the foothills of the Haut-Atlas. Tinghir covers a large diversity of agroclimatic environments from the rainfed plains to mountainous areas and oases. The province is characterized by a dry climate, with an average annual rainfall of $90 \mathrm{~mm}$ in the South and $200 \mathrm{~mm}$ in the north at higher altitudes. Snowfall is sometimes recorded in the high mountains from a peak of around $1,800 \mathrm{~m}$ (municipality of M'semrir). Rainfall often results in flash flooding of the oueds (dry river beds), causing losses to hydro-agricultural infrastructure and cultivated land. Very high temperatures in summer (over $40^{\circ} \mathrm{C}$ ) and very low in winter (down to $-5^{\circ} \mathrm{C}$ ) are recorded, accompanied by strong windy events (Statistical Yearbook of Morocco, 2016). The province of Tinghir is crossed by a few temporary rivers (oueds) and hydraulic basins. The agricultural and cultivated area accounts for about $1 \%$ of the provincial territory (12,800 ha) and is only possible with access to irrigation water. Landholdings are small, with average land ownership of 0.6 ha, underlining the trend toward land fragmentation in the region. The main annual crops include cereals (wheat and barley), alfalfa, and vegetables. The province is also known for its almond and olive trees and, more recently, apple plantations. Livestock activity based on sheep and goat grazing system constitutes the main farming activity accounting for over $98 \%$ of the territory.

\section{Data Collection and Sample}

Data collection was supervised by senior researchers and organized by a research team accompanied by university students, technicians and local extension agents in the two study areas. The sampling approach was guided in view to 


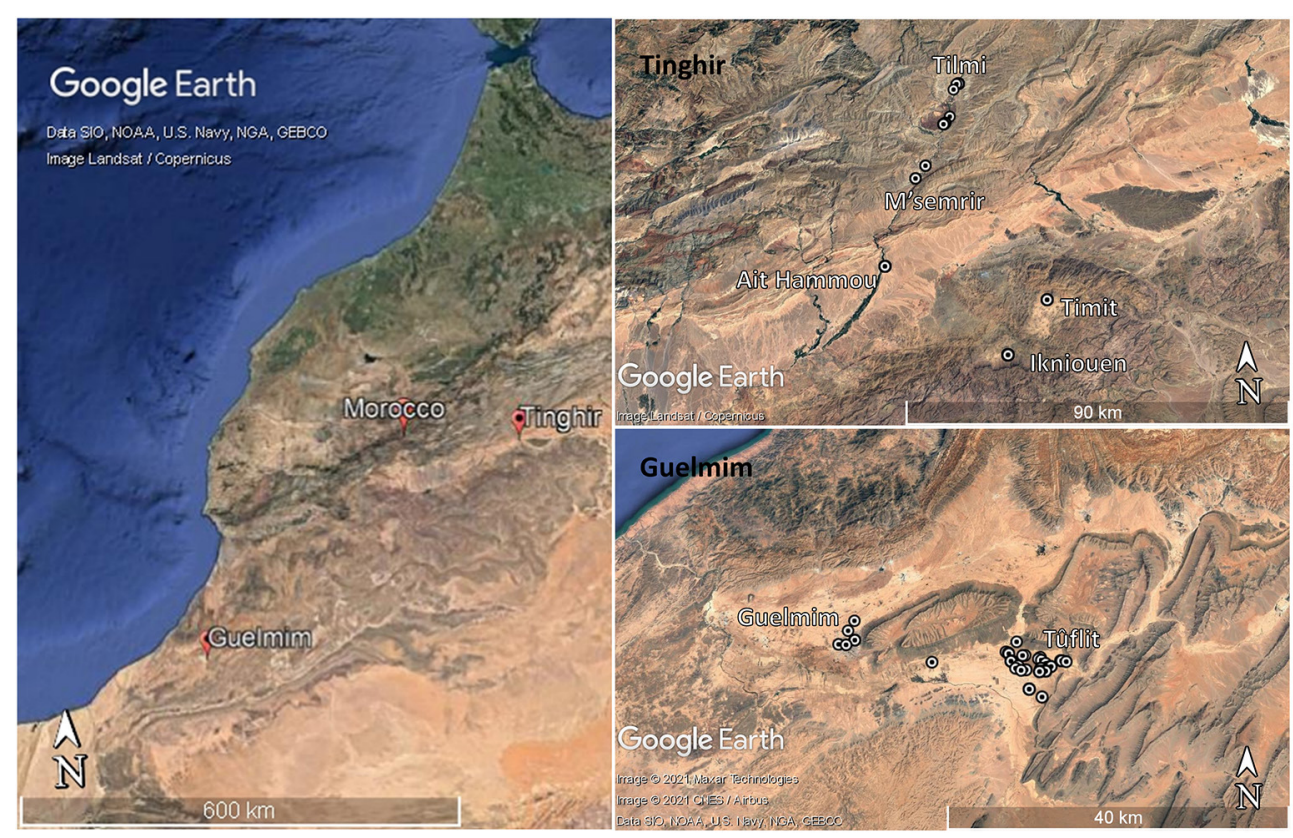

FIGURE 1 | Location of the two study areas in Morocco. White dots with black points indicate location of surveys (maps created using Google Earth).

capture the diversity of farm systems. Two criteria were selected: the camel-herd size in Guelmin and the geographical gradient along the Dadès valley in Tinghir. Then, we followed the snow ball sampling approach to identified the household farms in each category.

The data collected in Guelmin province was performed between April and August 2019. Fifty households were surveyed, subdivided between the city of Guelmim (4 households) and the rural area of "Tûflit" (46 households). The surveys conducted in the city of Guelmim were carried out directly with the herders in their homes. The household surveys in "Tûflit" were carried out either in the herders' tents and their families or in the grazing area (Noel, 2019). In Tinghir province, 36 household surveys were conducted between February and March 2020 along the valley of Dadès from the high elevation zone $(1,200 \mathrm{~m})$ to downstream of the valley in the direction of the oasis zone (Hrara, 2020). Our targeted groups were the pastoral and agropastoral systems based on small ruminants such as sheep and goats and few camels.

In addition, complementary interviews were conducted with key local stakeholders. The majority of them held a leadership position at the tribal or communal level as cheikhs (local tribal representatives) or president of the communes in Guelmim province and local authorities in Tinghir province. These interviews were open discussions in order to provide greater insight into the farming systems in the area, changes over time, and in particular, differences in living conditions and livelihood outcomes, that constituted the basis to build the livelihood outcome indicator.

We recognize that our sample can appear very small (total 96 households) compared to other studies. However, our sampling approach was reasoned to capture the diversity of farm systems based on open interviews with representative stakeholders. Moreover, our intention was not to conduct econometric analysis but mainly understanding the livelihood strategies and see how to improve the RHoMIS survey toolkit to apprehend these (agro)pastoral systems. We have also privileged open interviews in order to discuss indicators generated from data collection using RHoMIS adapted to this context through a new module regarding mobile herd-management.

\section{Adapted Farm Household Survey Based on RHoMIS Survey to Pastoral and Agropastoral Systems}

The household farm survey was based on a structured questionnaire using the RHoMIS Toolkit core modules. The RHoMIS toolkit, a Rural Household Multiple Indicator Survey, has been developed at the farm household level to assess and understand rural livelihoods. RHoMIS includes a farm household survey that can be conducted on a digital platform using tablets or mobile phones with the Open Data Kit (ODK) software adapted to Android-based mobile phones or tablets (Hartung et al., 2010; Hammond et al., 2017). The survey is a structured questionnaire that provides comprehensive information on standardized performance indicators concerning agricultural production, nutrition, food, and poverty. In total, the survey is structured in eight modules that address the specific components of the household activities and living conditions (see the modules in Table 1). The calculated indicators from the raw data make it possible to characterize and analyse the vulnerability of rural households while considering indicators concerning the conservation of the environment (Hammond et al., 2017). 
TABLE 1 | Structure and contents of the RHoMIS questionnaire used in Morocco.

\begin{tabular}{|c|c|c|}
\hline Module & Type of information & Analysiscategory \\
\hline $\begin{array}{l}\text { 1. Household } \\
\text { characterization }\end{array}$ & $\begin{array}{l}\text { 1) Head(s) of household } \\
\text { characteristics (age, level of } \\
\text { education, etc) } \\
\text { 2) Household composition } \\
\text { (members of household, their } \\
\text { age, gender, level of } \\
\text { education etc.). }\end{array}$ & Human capacities \\
\hline $\begin{array}{l}\text { 2. Information } \\
\text { on the } \\
\text { cropping } \\
\text { system }\end{array}$ & $\begin{array}{l}\text { 1) Land availability and } \\
\text { land ownership } \\
\text { 2) Crop management (crops } \\
\text { cultivated, inputs used etc.) } \\
\text { 3) Crop marketing (annual sales, } \\
\text { self-consumption, proportion } \\
\text { used for animal feed, etc.) } \\
\text { 4) Resource management (water } \\
\text { use and practices, soil } \\
\text { erosion, soil } \\
\text { fertility management) }\end{array}$ & $\begin{array}{l}\text { Farm crop } \\
\text { management and } \\
\text { marketing }\end{array}$ \\
\hline $\begin{array}{l}\text { 3. Information } \\
\text { on the } \\
\text { livestock } \\
\text { system }\end{array}$ & $\begin{array}{l}\text { 1) Livestock ownership and } \\
\text { composition (animal species, } \\
\text { heads etc.) } \\
\text { 2) Forage management by } \\
\text { livestock type and } \\
\text { physiological stage } \\
\text { 3) Livestock management in } \\
\text { terms of feed system (by } \\
\text { differentiating feeding system } \\
\text { in and out-door), health care, } \\
\text { and value production (milk, } \\
\text { meat, manure, etc.) } \\
\text { 4) Livestock marketing (annual } \\
\text { sales, self-consumption, a } \\
\text { proportion used for animal } \\
\text { feed, etc.) }\end{array}$ & $\begin{array}{l}\text { Livestock } \\
\text { management and } \\
\text { marketing }\end{array}$ \\
\hline $\begin{array}{l}\text { 4. Natural } \\
\text { resources }\end{array}$ & $\begin{array}{l}\text { 1) Use of natural resources, } \\
\text { especially plants, fruits, etc., } \\
\text { in the household food system. }\end{array}$ & $\begin{array}{l}\text { Biodiversity and } \\
\text { self-sufficiency }\end{array}$ \\
\hline $\begin{array}{l}\text { 5. Food } \\
\text { security }\end{array}$ & $\begin{array}{l}\text { 1) Dietary intake in terms of } \\
\text { diversity and food availability } \\
\text { 2) Dietary changes throughout } \\
\text { the year }\end{array}$ & Food (in)security \\
\hline $\begin{array}{l}\text { 6. Aid } \\
\text { received and } \\
\text { debts }\end{array}$ & $\begin{array}{l}\text { 1) Gifts, aids,and donations } \\
\text { (given and received) } \\
\text { 2) Loans and debts }\end{array}$ & $\begin{array}{l}\text { Appreciation of the } \\
\text { capacity to } \\
\text { mobilize social } \\
\text { resources }\end{array}$ \\
\hline $\begin{array}{l}\text { 7. Off-farm } \\
\text { income }\end{array}$ & $\begin{array}{l}\text { 1) External sources of income } \\
\text { and the nature of this income } \\
\text { 2) Use of off-farm income }\end{array}$ & $\begin{array}{l}\text { Off-farm } \\
\text { diversification }\end{array}$ \\
\hline $\begin{array}{l}\text { 8. Progress } \\
\text { Out of } \\
\text { Poverty Index }\end{array}$ & $\begin{array}{l}\text { 1) Based on national standard } \\
\text { indicators of poverty }\end{array}$ & $\begin{array}{l}\text { Livelihood } \\
\text { outcomes }\end{array}$ \\
\hline
\end{tabular}

We can question the use of RHoMIS compared to other data collection systems or compare the livelihood outcome indicator to other livelihood measurements. However, our main objective here was more to develop and adapt the RHoMIS survey toolkit to pastoral and agropastoral systems than compare different data collection systems such as LSMS (Living Standards Measurement Study), MICS (Multiple Indicator Cluster Surveys) or DHS (Demographic and health Survey) mainly focused on wealth indicators at the household level but not necessarily focusing on rural areas. Moreover, compared to these different data collection systems, RHoMIS proposes a light data collection system focusing on household farm system highlighting the diversity of farm and off farm activity in the livelihood conditions. Additionally, one of the main goals that supports this toolkit development is to have a standard tool that can be deployed on a large scale to constitute a database according to standardized criteria and thus facilitate comparison between different areas in the context of development actions (van Wijk et al., 2020). A data quality comparison with other survey tools, amongst which LSMS (World Bank, 2017) or IMPACTlite (Rufino et al., 2013) resulted in highly credible reliable core variables and derived indicators even if some improvements are always on-going (Fraval et al., 2019).

Particularly, in the present study, one of our aims was to develop and test a new version of the RHoMIS survey by developing and implementing a detailed livestock management approach by animal species applicable to dryland areas. We also wanted to explore and better understand the diverse contribution of each animal species through its management to well-being (in terms of income) and security (in terms of assets). As a result, a set of questions were included related to the structure of the herd by physiological stage, thus providing greater insight on the main objectives of the breeder. For example, when the herd was mainly composed of young male animals, we assumed that the breeding objective was to generate added value through livestock sales to market, with or without a fattening practice. On the other hand, when the herd comprised most adult females, this was assumed to be an indicator of the reproduction capacity in the face of a shock (like a severe drought or disease which results in a significant loss of the herd). Another set of questions were related to the animal transactions (entries and exit in the flock) to assess the monetary or non-monetary generated values from animal activities. Non-monetary transactions included all social flows of animals during family (birth, marriage) or community events (alliance, compensation, solidarity).

An additional component included in the survey concerned the approach of the sociotechnical management of animals to be able to assess the productivity and the net income of livestock activity. Notably, this section provided greater detail on herd management related to each animal species to describe the practices of indoor livestock management, the period and modalities of grazing management and mobility, and the supplemental feed practices for indoor or grazing herd-models. With this approach to herd-mobility management, it was possible to assess different variables related to individual or collective herd-mobility, the keeping modality, and the breeder's mobility capacity (in terms of distance) as part of the livelihood strategy (Amsidder et al., 2021). Additional questions were related to water management and animal watering regarding period and quantity and their relative costs.

Finally, we included an economic valuation for each type of animal product (milk, hides and skin, wool, or indirect income from tourism or leisure) and whether it was consumed by the household or sold to the market. An overview of the contents of the household farm survey is presented in Table $\mathbf{1}$. 


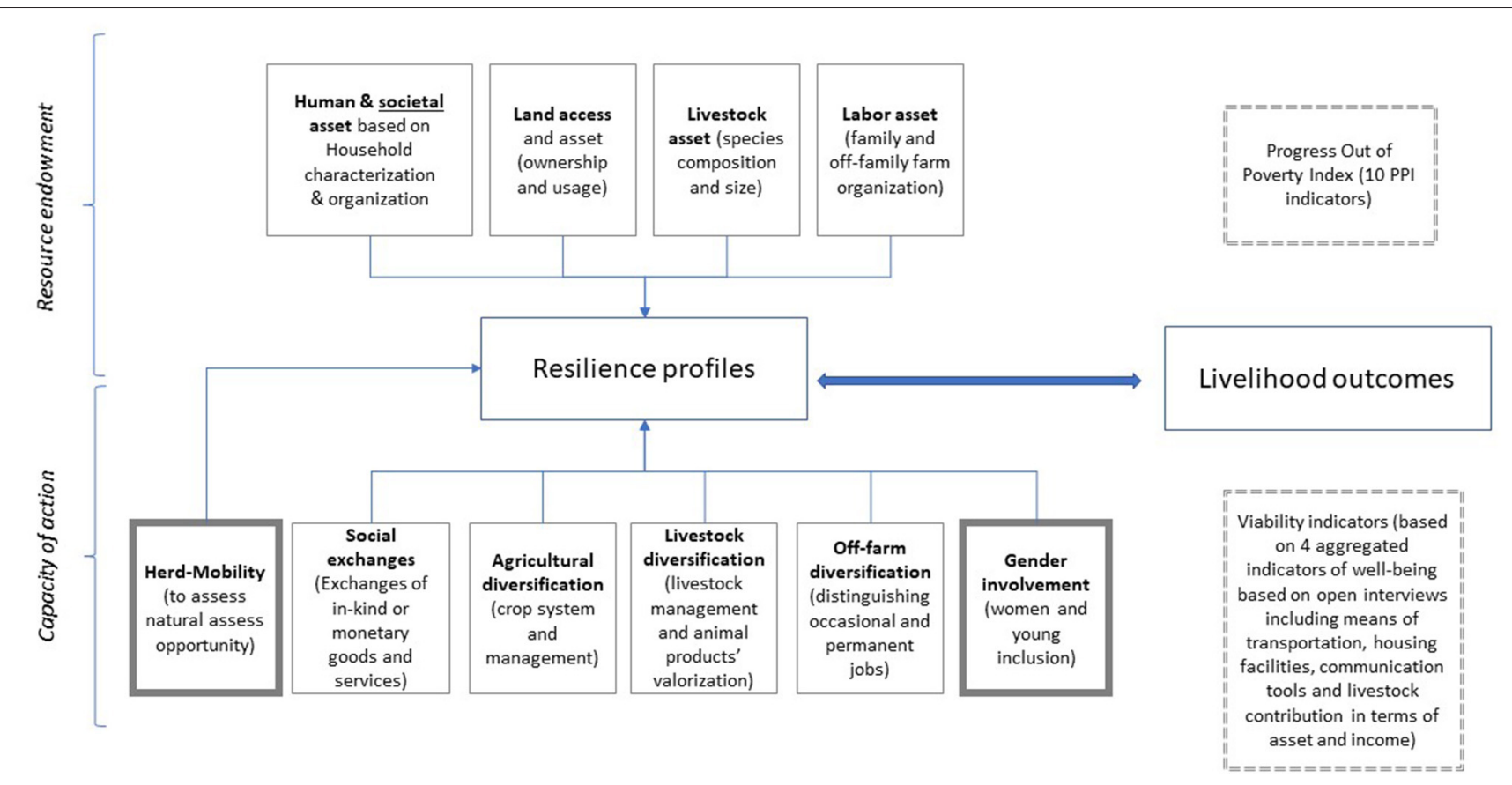

FIGURE 2 | Framework for analyzing the resilience profiles.

\section{Components of Resilience (Adaptive Capacity Indicators)}

Many studies assessing "sustainable livelihoods" at farm or household level refer to the sustainable livelihood framework conceptualized by Chambers and Conway (1991), combining capacity of action (Gondard-Delcroix and Rousseau, 2004) with stocks of assets (Lallau and Thibaut, 2009). Capacity of action is also embedded in the concepts of buffer, adaptive and transformative capacity described by Darnhofer (2014). In the current study, we took a similar approach by combining stocks of assets with capacity of action to create a set of 10 socioeconomic components of resilience (Figure 2, Table 2) related to physical and human endowments, capacity of action concerning crop diversification, livestock diversification, off-farm activities, and social management at the household and community level (see Supplementary Material 1 with the list of indicators).

Human labor, land, and livestock assets (resource endowment) were calculated based on usual asset variables related to each of these components as used in other studies (Supplementary Material 1). In pastoral and agropastoral contexts, the fifth set of bundles is grazing land access which depends on social network diversification, the natural ecosystem, and the formal and informal system of right and use. In our framework, this component was derived based on one main hypothesis that herd mobility management and its place in the functioning of the farm reflected the flexibility and, therefore the resilience of households when exposed to shocks, in particular in a harsh environment such as desert or mountainous areas where rainfall shortage constitutes a permanent and erratic risk (as also described in Davies and Nori, 2008; Nori, 2019).
The evaluation of crop, livestock and off farm diversification aimed to assess the capacity of action of households. For crop diversification, we selected variables related to cropland allocation, the relative use of inputs (such as chemical fertilizer and pesticides) and their on-or off-farm valorisation. Livestock diversification was evaluated based on the diversity of feed management in relation to herd mobility, and livestock products and co-products' multiple outcomes (mainly milk, meat and racing for camels) and their destinations (home-consumption or market). Off-farm diversification was a function of the nature of the contracts for the off-farm activity (seasonal or permanent).

In our framework, we proposed to include two distinct dimensions of capacity of action, i.e., "social exchanges," and "gender involvement". The "social exchanges" component was based on variables related to the social and financial exchanges of gifts, donations, or debts/loans. We assumed that the capacity to benefit from or give gifts or loans, reflects the place of the individual and his/her family in the community providing an appreciation of the social cohesion of the household, a "critical element in social stability and economic welfare" [as demonstrated by Narayan (1999)]. Moreover, this component attempts to reflect the diversity of functioning of the social exchanges by considering the gifts, donations and loan exchanges that can be in-kind or monetary value. In addition, we included a gender component to our set of resilience components in terms of capacity of actions. In this way, we assumed that the involvement of women or young people in the decision or accumulation (through entitlement) processes reinforces the overall capacity of action at the household level through diversification and enhancement of human capacity and social capital. 
TABLE 2 | Presentation of the main socio-economic components and list of indicators to describe adaptive capacity.

\begin{tabular}{|c|c|c|}
\hline $\begin{array}{l}\text { Component } \\
\text { of socio- } \\
\text { economic } \\
\text { resilience }\end{array}$ & $\begin{array}{l}\text { Indicator extracted from the } \\
\text { RHoMIS survey }\end{array}$ & Type of variable \\
\hline $\begin{array}{l}\text { Human } \\
\text { capacity }\end{array}$ & $\begin{array}{l}\text { Household characteristics such } \\
\text { as household size, age, and level } \\
\text { of education of the head of the } \\
\text { household }\end{array}$ & Active \\
\hline Labor asset & $\begin{array}{l}\text { Family size, hired labor, } \\
\text { exchange of labor }\end{array}$ & Active \\
\hline Land asset & $\begin{array}{l}\text { Land tenure, land cultivated, land } \\
\text { fragmentation }\end{array}$ & Active \\
\hline $\begin{array}{l}\text { Livestock } \\
\text { asset }\end{array}$ & Herd size by animal species & Active \\
\hline $\begin{array}{l}\text { Agricultural } \\
\text { diversification }\end{array}$ & $\begin{array}{l}\text { Crop diversification; crop } \\
\text { management (fertilization, } \\
\text { pesticide use, etc.) and crop } \\
\text { destination (self-consumption, } \\
\text { animal feed, or marketing) }\end{array}$ & Supplemental \\
\hline $\begin{array}{l}\text { Livestock } \\
\text { diversification }\end{array}$ & $\begin{array}{l}\text { Feed production, livestock } \\
\text { products and by-products (milk, } \\
\text { meat, racing, touristic activity) } \\
\text { and their destination }\end{array}$ & Supplemental \\
\hline $\begin{array}{l}\text { Off farm } \\
\text { diversification }\end{array}$ & $\begin{array}{l}\text { Type of non-farm activities } \\
\text { (occasional or permanent) and } \\
\text { monetary contribution; }\end{array}$ & Supplemental \\
\hline Social capital & $\begin{array}{l}\text { Exchange of gift (receive or give), } \\
\text { donations, or loans in the formal } \\
\text { or informal institutions; }\end{array}$ & Supplemental \\
\hline Mobility & $\begin{array}{l}\text { Herd mobility management } \\
\text { (individual or collective; use } \\
\text { external shepherd; the distance } \\
\text { of grazing land from the } \\
\text { settlement/village; etc.) in link } \\
\text { with social constraints/facilities } \\
\text { and natural resources } \\
\text { opportunity }\end{array}$ & Supplemental \\
\hline $\begin{array}{l}\text { Gender } \\
\text { involvement }\end{array}$ & $\begin{array}{l}\text { Women and young inclusion in } \\
\text { the decision and action } \\
\text { processes at the farm and off } \\
\text { farm level; }\end{array}$ & Supplemental \\
\hline
\end{tabular}

\section{Livelihood Outcomes Assessment}

In a first step, in order to understand the relationship between the resilience components and overall livelihood outcomes, we needed to approach an indicator of well-being to reflect the livelihood outcome. Well-being is a broad concept that encompasses a global judgment of satisfaction with life, including fulfillment of living conditions (e.g., housing, employment) but also contentment (like happiness or positive mood) (Diener et al., 2009). In this present work, well-being is approached in terms of contentment of living conditions based on the satisfaction of material life to compared with national standards. For that, we proposed to compare two aggregated indicators of "well-being." The first aggregated indicator was composed of the ten Progress Out of Poverty Index (PPI-www.povertyindex.org) criteria defined at national level, and which estimate the probability of poverty at the 95\% level of probability (Schreiner, 2007). This aggregated indicator enables the comparison of the overall poverty level in pastoral and agropastoral populations with the national population. The second indicator, that we have called "Viability," is composed of 4 sub-aggregated indicators addressing respectively, means of transportation (composed of the bicycle, the motorbike, car and the $4 \times 4$ car), housing facilities (tent or/and concrete), communications tools (including a smartphone), and a set of criteria related to net livestock income (animal assets and total net income per member of the family engaged full-time on-farm activities). These four sub-aggregated indicators were developed based on open interviews with key local informants (cheikhs-namely local authorities) and farmers. These open interviews aimed to identify the criteria that people used to classify a person or household as economically fragile or comfortable. For instance, local stakeholders and farmers used to categorize each other according to the type and age of car owned, the use of a smartphone as a means to be connected to WhatsApp groups, access to water, the housing material (including the tent), and herd-composition and size (see Supplementary Material 1).

In the second step, consistent with our sampling approach that focused on the analysis of the diversity of farming systems, we developed a household farm systems' typology, using a multiple correspondence analysis (MCA) on household asset variables and variables related to livelihood diversification and social management combined with the Ward method of hierarchical clustering (Ward, 1963) in each study site (respectively, in Guelmim and Tinghir). This factorial analysis technique is a descriptive approach that has the added advantage to be relevant with small sample. In our research, this set of methods was more applicable than econometric analysis that requires a large sample. The input variables comprised the set of resilience components (Table 2), transformed into discrete variables, combined with household assets as active variables (Table 2, col3), and diversification and social management as supplemental variables (see Supplementary Material 1). The adaptive capacity variables were transformed into discrete variables to capture their link to the function of resilience. They were transformed by the minimum score of 0 or 1 , indicating a null or lower value on the adaptive capacity contribution to a maximum score of 5. However, the scoring system's number varies between their amplitude and variability related to the variability in each location of our case study. The hierarchical clustering analysis identified three types of farm households in Guelmim and four types in Tinghir. To better understand and characterize the differences in livelihood characteristics among these household types, we calculated the means for different household characteristics including household demographics, off-farm diversification, access to land, livestock herd composition and structure, and livestock production for each household type.

In the third step, we tried to understand the links between "capacity of actions" and "resource endowment" and the two livelihood outcome indicators based on "PPI" and "Viability." For that, we developed a profile of resilience for each household type. To do this, for each resilience component, we first calculated 
the sum of the highest scores of each variable in the component for each study site, giving the maximum contribution for each component in the studied population. We then estimated the relative aggregated score of each component for each household by calculating the ratio of the sum of individual scores over the maximum potential contribution of the component in the studied population. To generate resilience profiles, we then calculated the mean component score by household type. The same formula was applied to the livelihood outcome indicators "PPI" and "Viability," enabling us to compare the resilience components with the level of living conditions and economic viability (PPI and viability).

In the last step, we tested and validated the sets of parameters selected in each component of the resilience profiles and analyzed the correlation with the two indicators of livelihood outcome, i.e. PPI and Viability. To achieve this, we performed a multiple factorial analysis (MFA) with the variables of the 10 components of resilience as active variables and the variables of the two components of livelihood outcomes (PPI and Viability) as supplemental variables.

\section{RESULTS}

\section{Characterization of Livestock Household Farm Systems' Types}

The main characteristics of the agropastoral and pastoral systems issued from two clustering analyses on the first factorial axis of the multiple correspondence analysis conducted in the two zones (descriptive statistics are given in Supplementary Material 2) are presented in Figure 3.

In Guelmim, we used the two first factors representing $17 \%$ of the variance of the sample. The first axis differentiated the large and specialized camel-based system (called "G3") and the diversified camel-system withcrop production (called "G1"). The second axis allowed the identification of a third group ("G2") representing the traditional agropastoral systems based on camel and small ruminants (sheep and goats). Group (G3) gathered the youngest family leaders who have developed a specialized camel-based system. In this group, family heads diversify their source of income by valorizing different camel activities, such as camel racing through the regional festivals and milk products, in addition to the sale of live animals. The second group (G2) corresponded to traditional agropastoral systems where camelherds move with a large flock of small ruminants (around 350400 animals), composed of two-third of sheep and one-third of goats. Finally, (G1) comprised the smallest camel-herd that grazed on communal land. This group benefited from communal land where they were able to grow, in rainy years, wheat for home consumption and barley for animals.

In Tinghir, the clustering analysis was performed on the coordinates of the individuals on the three first factors representing $33.6 \%$ of the variance. The first factor isolated group T2, representing the specialized pastoral system based on permanent grazing practices of a large flock (around 600 sheep and goats). Contrary to the others groups, this group (T2), mainly localized at higher altitude, and has not developed any crop activity. Factor 2 differentiated the diversified agropastoral systems according to the flock size, separating the group (T1) and (T3). The group (T1) comprised the extensive agropastoral system that kept around 400-450 animals. This group also owned the largest land area (around $6 \mathrm{ha}$ ) used to cultivate cereal or fodder crops. At the opposite side, group (T3) owned less than 100 sheep and goats, with most goats, on $<1.8$ ha of cultivated land. However, contrary to the last group (T4), the farmers in (T3) had developed a cattle activity (with around eight cattle). Finally, the last group (T4), was characterized by owning about 180-200 heads but without a cattle activity.

\section{Resilience Profiles and Livelihood Outcomes}

Based on this categorization of the agropastoral and pastoral systems, we generated the aggregated scores of each resilience component to assessthe associations with the livelihood outcome indicators based on "PPI" or the proposed aggregated indicator "Viability" composed of the criteria identified during our open interviews with the key stakeholders. Figure 4 presents the profiles of each system, respectively, for the camel-based systems in Guelmim (A) and sheep and goats-based systems in Tinghir (B).

Figure 4 reveals that livestock assets (Livestock_Tlu) differentiate the livestock farm systems' types in both study areas, but to a lower degree in Guelmim. However, we can observe that the large pastoral and agropastoral systems in both regions have both the maximum stock of animal assets. Another striking finding is that we observe contrasting variability in the spider diagrams between the two studied zones. Although the three camel-based systems in Guelmim present relatively similar profiles in terms of the combination of assets and capacity of action, we see more significant differences in the resilience profiles in the sheep and goats-based systems in Tinghir. Notably, in the sheep-goats-based systems, land asset and crop diversification are higher in the agropastoral systems than in mixed small-scale crop-livestock systems. This differentiation of land and crop-based systems reflects the differential capacity of investment allowed by a large flock. Besides, we can see that women and young are more involved in the specialized pastoral system than in the other mixed crop-livestock systems.

The livelihood outcome indicators also present different profiles of the resilience of the systems in Tinghir compared to Guelmim. PPI and Viability remain consistent for each household type in relation to livestock assets in arid zones in the camel-based system. However, in Tinghir, we observedifferences between these indicators for the large agropastoral (T1) and the pastoral system (T2), which record a low score for PPI compared to Viability. On the other hand, the diversified cattlesmall ruminant system (T3) recorded a higher score for PPI than Viability. The small-scale mixed crop-livestock system exhibited similar scores for the livelihood outcome variables. Furthermore, in Tinghir, while the PPI scores reveal better living conditions of the mixed crop-livestock system, Viability scores suggest that the pastoral and agropastoral systems have slightly higher resilience than the diversified crop-livestock systems. This contrasting 

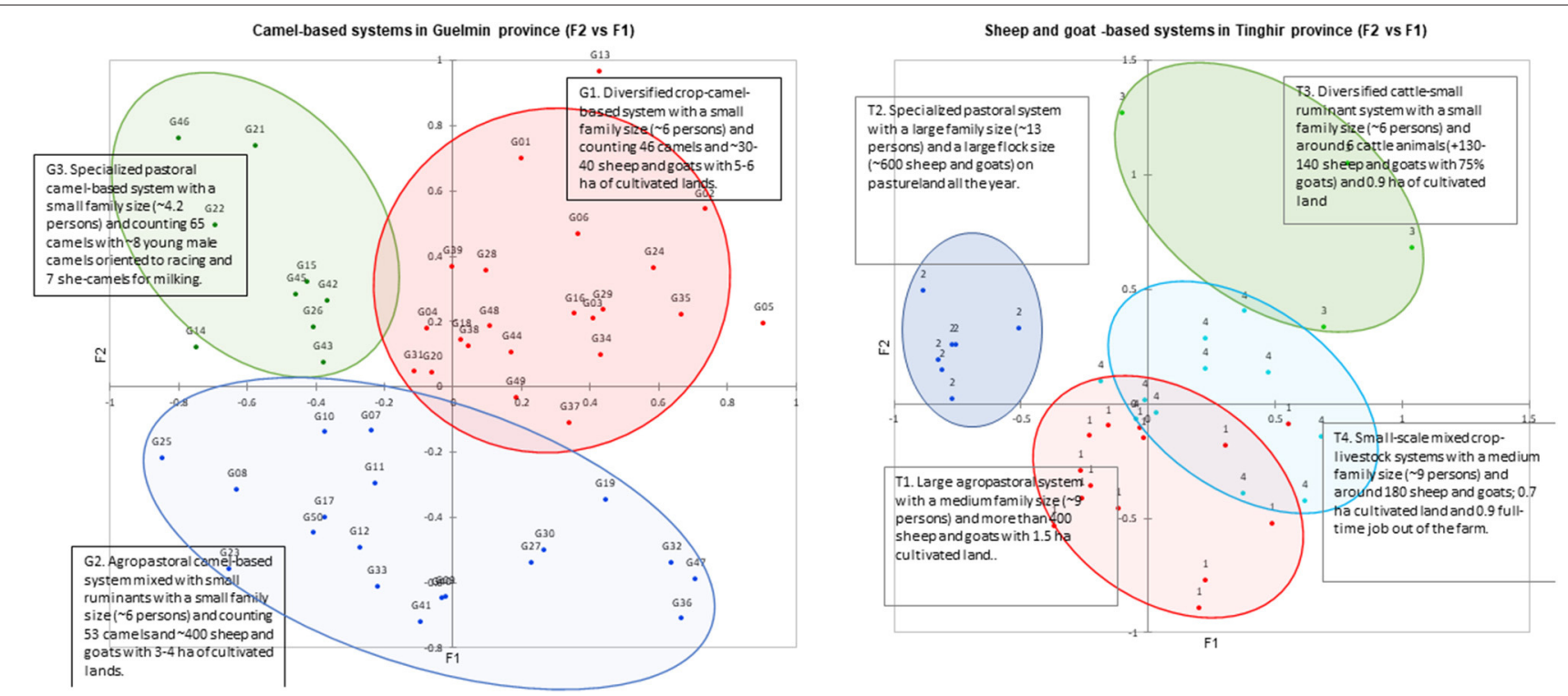

FIGURE 3 | Typology of livestock farming systems in the two studied sites (camel-based systems in Guelmim on the left and sheep and goats farming systems in Tinghir on the right)].

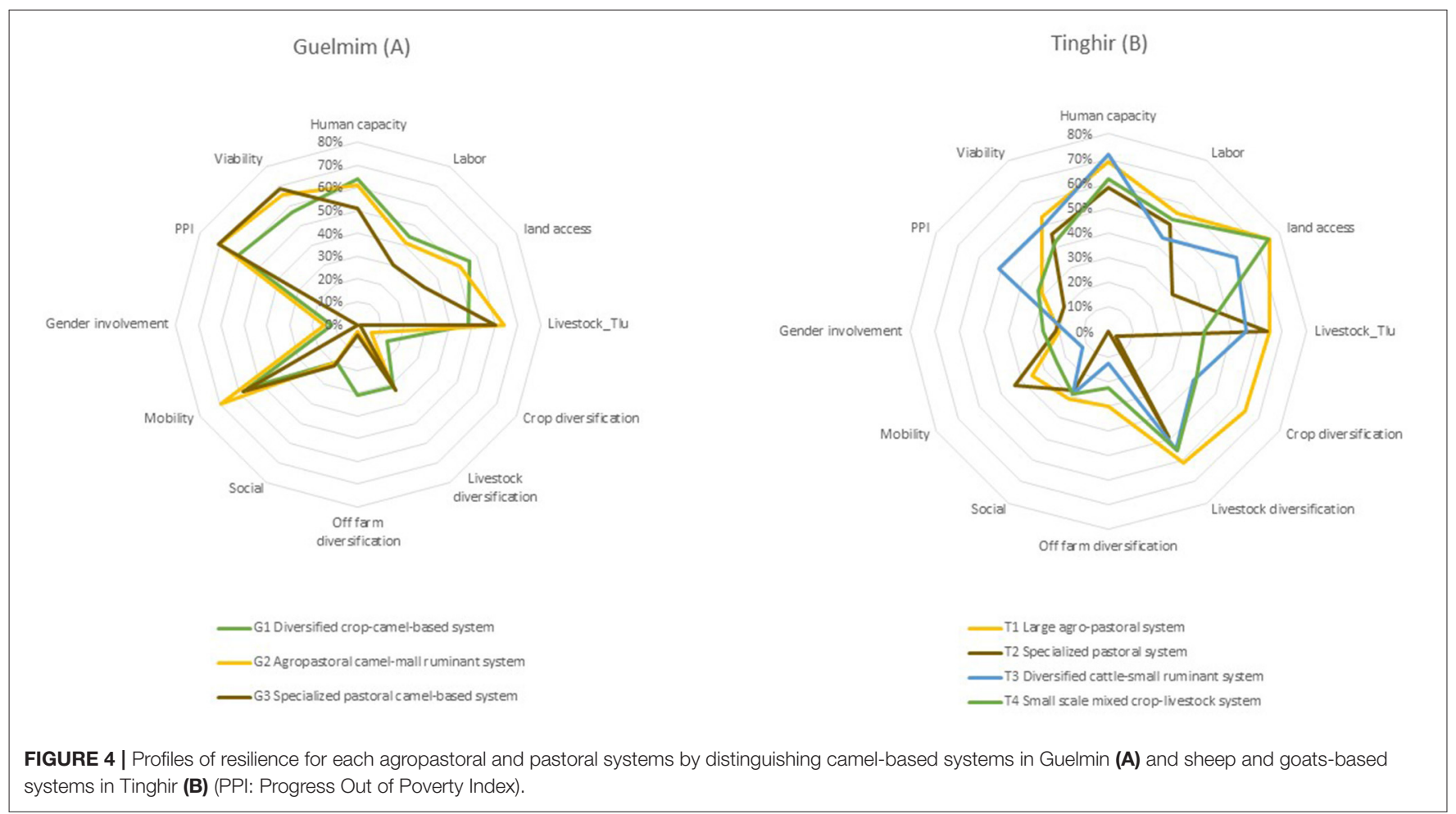

difference between PPI and Viability indicators is not observed for the camel-based systems in Guelmim where the main asset and diversification strategy are based on the camel animals.

Figure 5 shows that the PPI indicator reveal greater heterogeneity between sites, while the Viability indicator reveals greater heterogeneity within sites. We can see that the two indicators PPI and Viability present the most contrasting results for the two large agropastoral systems, i.e., the diversified crop-camel- based system (G1) in Guelmim and the large agropastoral system in Tinghir. Indeed, the Viability score enables the assessment of variability within site in associationwith the multiple outcomes of animal products and co-products compared to the PPI indicators which aremainly based on land and crop diversification (see Supplementary Material 3). 


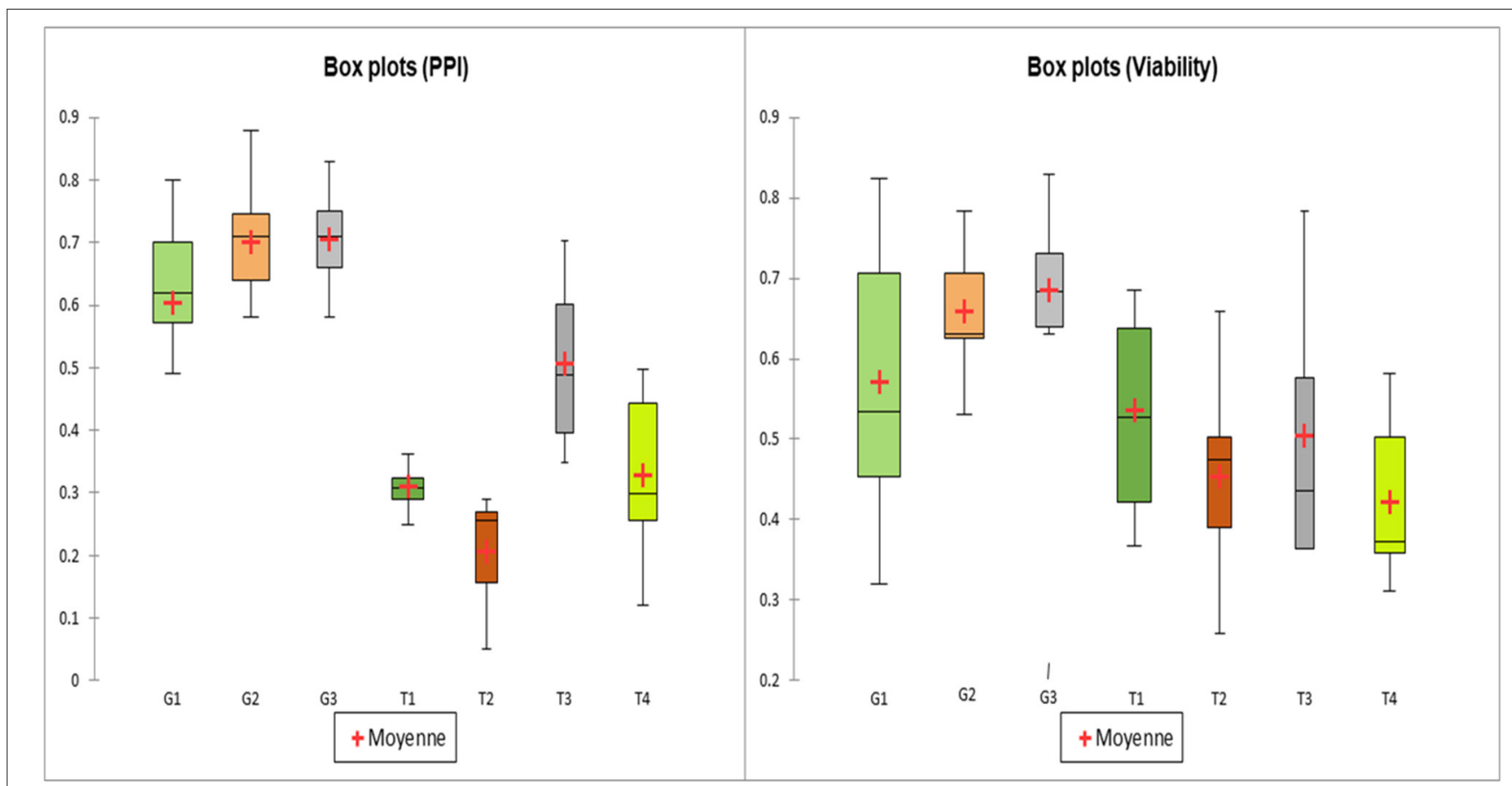

FIGURE 5 | Inter- and intra-heterogeneity of the livelihood outcome indicators for each agropastoral and pastoral systems in the two case studies. G1, Diversified crop-camel-based system; G2, Agropastoral camel-small ruminant system; G3, Specialized pastoral camel-based system; T1, Large agro-pastoral system in Tinghir; T2, Specialized pastoral system in Tinghir; T3, Diversified cattle-small ruminant system in Tinghir; T4, Small scale mixed crop-livestock system in Tinghir.

TABLE 3 | Matrix of correlation between the 10 themes and the indicators of livelihood.

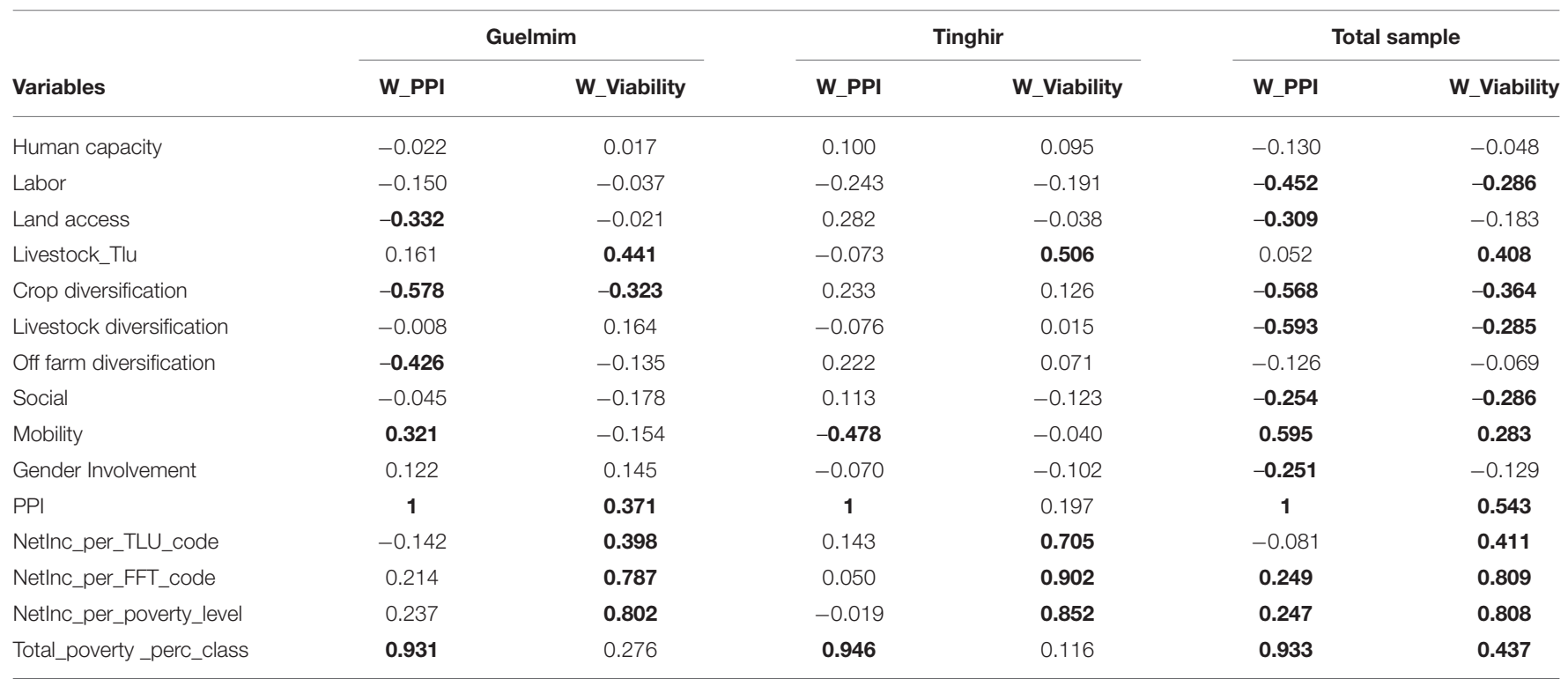

Values in bold are different from 0 at a significance level alpha $=0.05$

\section{Disaggregated Approach of the Resilience Based on the Resource Endowment and Capacity of Action}

To analyse the proximity between the livelihood outcome indicators and the capacity, we implemented a multiple factorial analysis conducted on the 10 components of the resilience profiles and including the two livelihood outcome indicators as supplemental variables. Table 3 presents the correlation matrix between the different scores for each component of the resilience profile representing the resource endowment 
and capacities of action with the two proposed indicators of livelihood outcomes.

A significant association was observed between PPI and Viability indicators, with a multivariate correlation coefficient (RV of 0.389 ). However, these two components of the livelihood approach differed slightly in regard to the profiles of stock of assets and capacity of action. On the one hand, the PPI component is relatively more associated with human capacity, crop diversification, and women or youth involvement in decision and control management than the "Viability." On the other hand, the "Viability" component is more associated to the "Mobility" and "Livestock-Tlu" components. Surprisingly, the stock of land and, to a lesser degree, labor organization have a more distant relationship with the two livelihood outcome indicators. In contrast, land access seems to be a more robust differentiating variable in the typology. The overall correlation between the components of the resilience profiles and the two livelihood outcome variables is slightly higher with PPI (RV = $0.549)$ than Viability $(\mathrm{RV}=0.438)$.

The matrix reveals also similarities in labor organization and crop and livestock diversification. The main differences in the correlations of each component with livelihood outcomes occur with the stock of assets components of the resilience profile. While there is a significant correlation between PPI and stock of land assets, this correlation is not significant with "Viability." Furthermore, we observe the opposite pattern with the inventory of livestock assets, with a positive and significant correlation with "Viability."

\section{DISCUSSION}

\section{Heterogeneity and Convergence in the Agropastoral and Pastoral Systems of South-Eastern Morocco}

It was notable that the resilience profiles of the farming household types were largely similar within each study site (Figure 4), indicating that the variability between sites was much greater than the variability found within sites. Given the contrasting agroecological and socio-economic contexts of these two rural agropastoral and pastoral systems of southand eastern Morocco, this may have been what one expected. However, a number of studies on mixed croplivestock systems suggest that household variations in asset holdings often outweigh larger-scale geographic, socio-cultural, and economic differences (Ellis and Bahiigwa, 2003; Ellis and Freeman, 2004; Tittonell et al., 2005). Our results on the other hand align with other studies more focused on agropastoral and pastoral systems that emphasize the effect of location specific factors in determining resilience (Abebe, 2020; Melketo et al., 2021). As a number of such studies indicate, context-specific factors such as climate, disaster-risk proneness, distance to market, access to irrigation, access to credit, local politics among others are important determinants of household resilience(Perez et al., 2015; Bera et al., 2020). These contrasting results between livestock or crop-oriented systems may indicate important differences in factors affecting overall household resilience.

Taking a closer look at the differences in the resilience profiles between sites, the major differences tended to be associated with livelihood diversification [off-farm diversification, livestock diversification, and crop diversification, considered in the capacities of action in our frame (Figure 2)], where household types from Tinghir were more diversified than the household types from Guelmim (Figure 4). Moreover, within site, the variability in livelihood diversification was greater in Tinghir compared to Guelmim, with household type of specialized pastoral systems in Tinghir (T2) displaying much lower levels of diversification in terms of off-farm diversification or crop-diversification compared to the other household types in Tinghir. These differences between and within sites in livelihood diversification are especially important as livelihood diversification is often identified as a key strategy in building household resilience (Wu et al., 2014; Martin and Lorenzen, 2016; Sarker et al., 2020).

One of the main reasons for the differences in livelihood diversification between sites is likely a result of the overall vulnerability of the households of the two sites. As observed in the livelihood outcome variables (PPI and Viability-Figures 4, 5), households from Guelmim are much less prone to poverty and their livelihood strategies are much more viable than the households from Tinghir. While livelihood strategies with no doubt contribute to livelihood outcomes, there is also an important iterative process or bi-directional dependence between resilience profiles and livelihood outcomessuch that livelihood outcomes will also influence the livelihood strategies employed by the farming households (Figure 2). In this sense, the farming households of Tinghir are compelled toward livelihood diversification strategies in order to build resilience in the face of higher levels of poverty and lower levels of livelihood viability, placing them in positions of greater vulnerability. This finding closely reflects the conclusions of a recent study investigating livelihood diversification in a riverine context in rural Bangladesh. In this study it was shown that resource poor households tended to exhibit greater livelihood diversification than resource richer households (Sarker et al., 2020).

On the other hand, the comparatively improved livelihood outcomes of the farming households in Guelmim coupled with the economic opportunities presented by an easily accessible urban center nearby are key factors that may enable these households to thrive by adopting more specialized, less diverse, livelihood strategies. The most extreme example of this is with the specialized pastoral camel-based systems(G3) that specialized in pastoral camel systems generating significant proportions of their income through niche activities related to camel racing (see Supplementary Material 2). This finding reflects the conclusions from a study in Botswana, where, when the conditions were conducive, wealthier and more powerful households often employed "accumulator" livelihood strategies specializing in the rearing of livestock (Sallu et al., 2010). Besides, we need to mention that the Guelmim-Oued Noun region, at the gate to the Sahara, has also benefitted from 
significant support, especially from the state. This support has followed the Sahara conflict which had implied important investments in terms of infrastructure (mainly roads) and a settlement of civilians as well as military troops. This situation differs significantly from Tinghir, which is not an important trade route. However, the two areas always receive barley grains at a subsidized price that were considered into the net income calculation.

With regard to the greater variability in livelihood diversification within Tinghir, it appears that these differences may be driven by access to land. Specifically, as noted above, T2 farming households differed from the other household types in Tinghir as their crop and off-farm diversification levels were much lower. It is likely that the lack of livelihood diversification among these households was a result of lower levels in land access, the other resilience component that displayed important differences among household types in Tinghir (Figure 4). Leading a fully pastoral lifestyle without owning or cultivating land prevents livelihood diversification into crops. Furthermore, it is likely that a full mobile pastoral lifestyle is also very labor intensive as indicated by the number of males and females in the household active on-farm (Supplementary Material 2). This is confirmed by the particular profile of gender involvement for T2. Women and young are strongly involved in mobility management throughout the year. This also prevents livelihood diversification through off-farm income generating activities as more members of the family are employed on-farm.

Although many studies in pastoral areas have highlighted the role of livestock as social capital (Thébaud and Batterbury, 2001; McCarthy and Di Gregorio, 2007; Moritz, 2008), Figure 4 displays weak variation of the social exchanges in association with the different profiles of resilience. Indeed, our results tended to display a negative correlation between social exchanges and livelihood outcomes indicators. In fact, the social exchanges in terms of loans or gifts in kind or money are more developed in the less resilience population. However, we cannot omit that the present approach does not reflect the real exchanges of live animals that have been difficult to capture in our survey.

These mobile, but landless, households therefore face significant structural barriers to livelihood diversification due to their inability to exploit opportunities for further income generation either through crop production or off-farm activities. Without these pathways to building resilience, it is likely that they will remain particularly vulnerable compared to the other farming households in the area. As such, our results support other research that suggest pastoral systems in Morocco will face even greater existential threats in the coming decades due to a variety of environmental (e.g., climate and land-degradation) and socioeconomic (e.g., land-use change and household characteristics) factors (Martin et al., 2016; Schilling et al., 2020). Indeed, as a recent study has shown these threats are leading to a consistent trend toward the conversion of pastoral land to agricultural land in southeast Morocco (Lamqadem et al., 2019). Greater investment in long-term management of rangelands and pastoral livelihood security is therefore key to supporting these farming households (Martin et al., 2016).

\section{Indicators of Livelihood Outcomes and Perspectives}

The comparative analysis of household resilience and livelihood outcomes for the different identified livestock farming systems in Morocco based on herd-mobility revealed the different roles of each animal species in their contribution to the overall resilience profiles and, consequently, their impact on the livelihood outcome indicators. In Guelmim, we noted large similarities between PPI and Viability indicators in line with animal stocks, mainly defined by camel assets. Conversely, the relations between animal stock and livelihoods outcome indicators present different configurations in the sheep and goat-based systems according to the complementary role of crop and off-farm activities, family size, and how to conceive the livelihood measurement. As soon as the system is based on large ruminants like cattle in the "diversified cattle-small ruminant system in Tinghir" (T3), we note similar profiles for PPI and Viability livelihood indicators. The similarity of livestock conditions is also observed for the small-scale mixed crop-livestock system (T4) with a relatively good land basis compared to the other types in the sample. On the other hand, we note significant differences between PPI and Viability indicators regarding the pastoral and agropastoral systems based on sheep and goats. The "Viability" indicator better reflects the capital related to animal stock and animal diversification outcome. So, this result questions the use of the PPI indicator as a livelihood measurement in the pastoral systems based on small ruminants.

Understanding this contrasting result between systems oriented to large ruminants or small ruminants is explained by the different roles played by animal species in the overall livelihood outcomes (Alary et al., 2011, 2015). Linking these results with the framework proposed in Darnhofer (2014) who highlights three aspects covered by resilience, i.e., buffer capability, adaptive capability and transformative capability, this analysis highlights the larger contribution of camels and cattle in terms of transformative capacity of the household system, contrary to sheep and goats that can generate important monetary fluxes but not necessarily physical accumulation (either for housing or farming). As such we can argue that sheep and goats increase the "buffer" and even "adaptive" capacity of rural households in case of shocks, but not necessarily their "transformative" capacity. Here the buffer and adaptive capacities refer to the concept of farm resilience developed by Milestad and Darnhofer (2003) and used in different research works (e.g., Speranza, 2013).

In parallel, the interviews with key stakeholders in each area allowed us to get an insight into some common perceptions about the livelihoods of the different farm groups based on herd size. For instance, in Guelmim, families can rapidly have an idea about the living conditions of each other based on camel-herd and sheep-goats flock size. According to a number of interviewees, a family with more than 50 heads of camel, lives well. Below this threshold, "it will depend on the sheep and goats flock size...with 200 sheep and goats, a family can achieve similar living conditions to families with more than 50 camels" (declaration). These explanations align closely with the 
household types that were defined through the MCA and the corresponding livelihood outcome indicators (PPI and Viability). Group (G3) comprised the farmers with more than 50 camels, while groups G1 and G2 represented the households with or without the complement sheep and goats flock. In Tinghir, the discussions conducted with key stakeholders highlighted the contrasting living situations between the pastoral systems in the mountainous zones from the agropastoral or mixed systems along the Dadès valley. The typology reflected these distinctions too, clearly defining the transition from pastoral to integrated crop-livestock systems along the valley. The livelihood outcomes indicators put in exergue different capacities, i.e., the capacity of action for mixed systems through the PPI and the resource endowment for large pastoral systems through the Viability score. We can note that the "Viability" score through a set of performance indicators related to income address the monetary poverty (see Supplementary Material 2).

With regard to the proposed conceptual frame work outlined in Figure 2, we can conclude that the "PPI" livelihood outcome indicator conceived at the national level, remains a relatively good proxy of the living conditions of pastoral and agropastoral systems based on large ruminants. On the other hand, the "Viability" indicator highlights relatively well the combination of endowments and diversity described in the resilience profiles (like proposed by Chambers and Conway, 1991). This indicator considers the variety of system components and diversity of livelihood options that confer a certain degree of flexibility and then an adaptive capacity in their livelihood strategies (as also observed in Robert and Lallau, 2016).

Moreover, notwithstanding these findings, it is important to note that with our methodological approach, the transformation of the raw or calculated data into discrete variables to capture their association to resilience raises some issues. For example, the collective management of a livestock herd with different herdowners can be either perceived as an indicator of robustness (if this enables livestock-breeders to exploita larger territory in relation to a social network) or vulnerability when herd-owners are forced to participate in collective management due to lack of equipment or human resources to conduct mobility alone. To better understand these dynamics within the local contexts of the research areas, the research teams used the formal and informal interviews that were conducted with community elders and local key stakeholders in the form of life stories (by referring to the approach of Vincent-Ponroy and Chevalier, 2018). However, this point raises the question whether such a variable should then be included as an indicator of resilience when attempting to develop a generic approach for the assessment of resilience profiles of pastoral and agropastoral systems? Moreover, would it be more appropriate to explore the underlying drivers, i.e., access to equipment and human resources? However, it is well recognized that the approach focusing on drivers does not solve the problem completely, especially from the perspective of using collective management as a form of generating greater resilience. Collective management seems to be both a product of vulnerability and an opportunity to achieve greater access to land. As such we argue that this approach requires a context-specific scoring system for some indicators. Only the set of proposed indicators constitute a sound basis to approach the diversity of livelihood strategies of pastoral and agro-pastoral systems. This list of proposed indicators is currently analyzed in front of a diversity of (agro) pastoral systems through an expert group working in North and Sub-Saharan African countries. Another step will be to compare livelihood outcomes indicators with other livelihood measurements as discussed by Alkire (2002), Ramos and Solber (2005) or by McPeak et al. (2011) for (agro) pastoral households. The presented development of data collection and research on composite indicators to capture livelihood status in pastoral systems highlights the need to work more on clusters of indicators rather than a single indicator of livelihood outcome in these systems, considering the multiple and variable functions of animal species. Finally, as also mentioned in McPeak et al. (2011), capturing the direct and indirect flows from the social and economic transactions around livestock activities such as gifts and transfers also remains a challenge.

\section{CONCLUSION AND PERSPECTIVES}

The results clearly show that understanding the multiple functions of livestock assets as well as the heterogeneity of the production systems of breeders and their families constitutes a first and unmissable step in the elaboration of compatible development options to improve the livelihood conditions of pastoral and agropastoral systems living in these arid and uncultivable areas.The proposed framework allowed us to capture the bi-directional dependence between resilience profiles and livelihood outcomes. Notably, our case study highlighted the fact that livelihood outcomes are both a product and a determinant of resilience profiles. This holistic approach based on factorial analysis also highlighted the structural barriers to livelihood diversification of some pastoral and agropastoral systems. These barriers are related tothe degree of ability to exploit opportunities for further income generation either through crop production or off-farm activities. Furthermore, this ability is also conditioned by livestock composition and, consequently, the potential accumulation process in and out of agriculture. However, one of the main bases of this dynamic is firmly embedded in the long-term management of rangelands that condition pastoral livelihood security over time.

From a methodological point of view, our work allowed to develop an operational framework for addressing and assessing living conditions of farming household whose livelihoods depend on livestock incomes in dryland areas. This approach underlines the multiple roles that livestock can play in relation to animal assets and their management and the role of complementary activities such as crop cultivation or off-farm activities. However, this approach also highlights heterogeneities due to the context that conditions different opportunities of diversification (capacity of action), also involving different needs and development options. This context-specific factor reinforces the need to employ a solid database collection system, enabling the capture of both general and specific components of resilience profiles based on a holistic approach. In this line, RHoMIS constitutes a sound basis for data collection, allowing to some 
local adaptation. The new version of the livestock modules developed within this work and the performance indicators developed within this current framework presented in the paper could be an excellent basis to define resilience profiles considering the organization and functioning of household systems based on mobile livestock activity. Moreover, this approach could constitute a valuable contribution to help fill the knowledge gaps that limit policy makers in developing contextualized rural development policies and instruments in these very vulnerable environments where livelihood outcomes are mainly based on livestock asset.

\section{DATA AVAILABILITY STATEMENT}

The raw data supporting the conclusions of this article will be made available by the authors, without undue reservation.

\section{ETHICS STATEMENT}

The studies involving human participants were reviewed and approved by approval and consentement of the surveyed persons. Written informed consent for participation was not required for this study in accordance with the national legislation and the institutional requirements.

\section{AUTHOR CONTRIBUTIONS}

VA, LA, JH, MV, IB, and TS contributed to conception and design of the study. XJ and AS organized the database. VA, XJ, and MC performed the statistical analysis. VA wrote the first draft of the manuscript. MC wrote sections of the manuscript. All authors contributed to manuscript revision, read, and approved the submitted version.

\section{REFERENCES}

Abebe, G. (2020). Cash-for-work and food-for-work programmes' role in household resilience to food insecurity in southern Ethiopia. Develop. Pract. 30, 1068-1081. doi: 10.1080/09614524.2020. 1747398

Adger, N. W. (2000). Social and ecological resilience: are they related? Prog. Hum. Geogr. 24, 347-364. doi: 10.1191/03091320070 1540465

Adger, W. N., Dessai, S., Goulden, M., Hulme, M., Lorenzoni, I., Nelson, D. R., et al. (2009). Are there social limits to adaptation to climate change? Climatic Change 93:335. doi: 10.1007/s10584-008-9520-Z

Alary, V., Aboul-Naga, A., El Shafie, M., Abdelkrim, N., Hamdon, H., and Metawi, H. (2015). Roles of small ruminants in rural livelihood improvementcomparative analysis in Egypt. Rev. Elev. Med. Vet. Pays Trop. 68, 79-85. doi: $10.19182 /$ remvt.20592

Alary, V., Corniaux, C., and Gautier, D. (2011). Livestock's contribution to poverty alleviation: how to measure it? World develop. 39, 1638-1648. doi: 10.1016/j.worlddev.2011.02.008

Alkire, S. (2002). Dimensions of human development. World develop. 30, 181-205. doi: 10.1016/S0305-750X(01)00109-7

Amsidder, L., Alary, V., and Sraïri, M. T. (2021). An empirical approach of past and present mobility management in the desert societies of camel breeders in South Eastern Morocco. J. Arid Environ. 189:104501. doi: $10.1016 /$ j.jaridenv.2021.104501

\section{ACKNOWLEDGMENTS}

The fieldworks of the two case studies have been conducted in collaboration between the CRP Livestock Program within the CGIAR System (Livestock Livelihoods and Agri-Food Systems (LLAFs) flagship) and two research projects: the CARAVAN project on "Toward a Camel tRAnsnational VAlue chain" (ARIMnet project coordinated by the University of Cordoba and funded by the French Agency of National Research (ANR) for the presented fieldwork in Morocco) and the MASSIRE project on "Integrating multiple water sources and local institutions for enhanced food security in North Africa's hinterland by reinforcing agricultural and rural innovation systems" (research and development IFAD project coordinated by CIRAD). We would like to thank all the donors that have supported this work, i.e., all donors and organizations who globally support the work of the CGIAR Research Program on Livestock, ANR and IFAD. We would also like to thank the different development agencies in the two provinces, mainly the Regional Direction of Agriculture (DRA) in the region Guelmim-Oued-Noun and the ORMVAO (Office Régional de Mise enValeur Agricole de Ouarzazate) in the province of Ouarzazate, and particularly M. Kabiri (DRA, Guelmim-Oued Noun) and A. Ramdane (ORMVAO, Ouarzazate).We also thank the two students, Justine Noël (ISTOM, France) and Abir Hrara (IAV Hassan II, Morocco), who have contributed to the data collection in the two areas.

\section{SUPPLEMENTARY MATERIAL}

The Supplementary Material for this article can be found online at: https://www.frontiersin.org/articles/10.3389/fsufs. 2021.723994/full\#supplementary-material

Attou, M. B., and Belkadi, A. (2014). Guelmim-Oued Noun: la ville, la tribu et le processus d'urbanisation. Maroc: Faculté des Lettres des Sciences Humaines Université Ibn Zohr. p. 194.

Bera, S., Guru, B., Chatterjee, R., and Shaw, R. (2020). Geographic variation of resilience to landslide hazard: a household-based comparative studies in Kalimpong hilly region, India. Int. J. Disaster Risk Reduct. 46:101456. doi: 10.1016/j.ijdrr.2019.101456

Berkes, F., Colding, J., and Folke, C. (2003). Navigating Social-Ecological Systems: Building Resilience for Complexity and Change. Cambridge: Cambridge University Press.

Chambers, R., and Conway, G. R. (1991). Sustainable Rural Livelihoods: Practical Concepts for the 21st Century. IDS Discussion Paper 296, IDS (Institute of Development Studies), UK. 33 pp.

Darnhofer, I. (2014). Resilience and why it matters for farm management. Eur. Rev. Agric. Econ. 41, 461-484. doi: 10.1093/erae/jbu012

Darnhofer, I., Bellon, S., Dedieu, B., and Milestad, R. (2010). Adaptiveness to enhance the sustainability of farming systems. a review. Agron. Sust. Dev. 30, 545-555. doi: 10.1051/agro/2009053

Davies, J., and Nori, M. (2008). Managing and mitigating climate change through pastoralism. Policy Matters, 9.Gland: IUCN.

Davoudi, S., Shaw, K., Haider, L. J., Quinlan, A. E., Peterson, G. D, Wilkinson, C., et al. (2012). Resilience: a bridging concept or a dead end? "reframing" resilience: Challenges for planning theory and practice interacting traps: resilience assessment of a pasture management system in northern afghanistan urban resilience: what does it mean in planning practice? resilience as a 
useful concept for climate change adaptation? Resilience. 13:2, 299-333. doi: 10.1080/14649357.2012.677124

Diener, E., Scollon, C. N., and Lucas, R. E. (2009). "The evolving concept of subjective well-being: the multifaceted nature of happiness," in Assessing Wellbeing: The Collected Works of Ed Diener, ed E Diener (New York, NY: Springer), 67-100.

Eakin, H., Lemos, M., and Nelson, D. (2014). Differentiating capacities as a means to sustainable climate change adaptation. Global Environ. Change 27, 1-8. doi: 10.1016/j.gloenvcha.2014.04.013

Ellis, F., and Bahiigwa, G. (2003). Livelihoods and rural poverty reduction in Uganda. World Develop. 31, 997-1013. doi: 10.1016/S0305-750X(03)00043-3

Ellis, F., and Freeman, H. A. (2004).. Rural livelihoods and poverty reduction strategies in four African countries. J. Develop. Stud. 40, 1-30. doi: 10.1080/00220380410001673175

FAO (2018). Pastoralism in Africa's Drylands: Reducing Risks, Addressing Vulnerability and Enhancing Resilience. Rome: FAO. p. 52. Available Online at: https://www.fao.org/3/CA1312EN/ca1312en.pdf

Folke, C. (2016). Resilience . Ecol. Soc. 21, 44-48. doi: 10.5751/ES-09088-210444

Folke, C., Carpenter, S. R., Walker, B., Scheffer, M., Chapin, T., and Rockström, J. (2010) Resilience thinking: integrating resilience, adaptability and transformability. Ecol. Soc. 15, 20-25. Available Online at: http://www. ecologyandsociety.org/vol15/iss4/art20/

Fraval, S., Hammond, J., Wichern, J., Oosting, S., De Boer, I., and Teufel, N., et al (2019). Making the most of imperfect data: a critical evaluation of standard information collected in farm household surveys. Exp. Agric. 55, 230-250. doi: $10.1017 /$ S0014479718000388

Gondard-Delcroix, C., and Rousseau, S. (2004). Vulnérabilité et stratégie durable de gestion des risques: une étude appliquée aux ménages ruraux de Madagascar. Développement Durable et Territoire 4:1143. doi: 10.4000/developpementdurable.1143

Grameen Foundation (2014). Global Report on Poverty Measurement with the Progress out of Poverty Index ${ }^{\circledR}$. Available Online at: https://www.povertyindex. org/sites/default/files/PPI\%20Global\%20Report\%202014.pdf

Haddad, F. F., Ariza, C., and Malmer, A. (2021). Building climate-resilient dryland forests and agrosilvopastoral production systems: An approach for contextdependent economic, social and environmentally sustainable transformations. Forestry Working Paper No. 22. Food and Agriculture Organization of the United Nations, Rome.

Hammond, J., Fraval, S., Etten, J., van, Suchini, J. G., Mercado, L., Pagella, T., et al. (2017). The Rural Household Multi-Indicator Survey (RHoMIS) for rapid characterisation of households to inform climate smart agriculture interventions: Description and applications in East Africa and Central America. Agricult. Syst. 151:225-233. doi: 10.1016/j.agsy.2016. 05.003

Hartung, C., Lerer, A., Anokwa, Y., Tseng, C., Brunette, W., and Borriello, G. (2010). "Opendata kit: tools to build information services for developing regions," in Proceedingsofthe $4^{\text {th }}$ ACM/IEEE international conference on information and communication technologies and development, p. 18.

Hrara, A. (2020). La contribution de l'élevage pastoral dans l'amélioration des conditions de vie des foyers ruraux au niveau de la zone de Tinghir. Projet de fin d'études, Institut Agronomique et Vétérinaire Hassan II, Rabat (Maroc), encadré par Véronique Alary (CIRAD, ICARDA) et Pr. Mohamed Taher Sraïri (IAV Hassan II).

Janssen, M. A., and Ostrom, E. (2006). Editorial: Resilience, vulnerability, and adaptation: a cross-cutting theme of the International Human Dimensions Programme on Global Environmental Change. Glob. Environ. Change 16, 237-239.

Lallau, B., and Thibaut, E. (2009). La résilience en débat: Quel devenir pour les agriculteurs en difficulté? Revue d'études en agriculture et environnement, 90, 79-102.

Lamqadem, A. A., Saber, H., and Pradhan, B. (2019). Long term monitoring of transformation from pastoral to agricultural land use using time series landsat data in the Feija Basin (Southeast). Earth Syst. Environ. 3, 525-538. doi: 10.1007/s41748-019-00110-3

Lazarev, G., and Kadi, M. A. (2012). Les politiques agraires au Maroc 1956-2006: un témoignage engagé. Paris, France:Economie critique, p. 232.

Leach, M., Scoones, I., and Stirling, A. (2007). Pathways to Sustainability: An Overview of the STEPS Centre Approach. London: STEPS Centre.
Li, M., Huo, X., Peng, C., Qiu, H., Shangguan, Z., Chang, C. (2017). Complementary livelihood capital as a means to enhance adaptive capacity: a case of the Loess Plateau, China. Global Environ. Change 47, 143-152. doi: 10.1016/j.gloenvcha.2017.10.004

Linstädter, A., Kuhn, A., Nauman, C., Rasch, S., Sandhage-Hofmann, A., Amelung, W., et al. (2016). Assessing the resilience of a real-world social-ecological system: lessons from a multidisciplinary evaluation of a South African pastoral system. Ecol. Soc. 21, 35-42.

Mahdi, M. (2015). Pastoralisme nomade au Sahara: mercantilisme, survie et hédonisme. Maroc: Centre des Etudes Sahariennes, p. 77p.

Martin, L. (2011). Le dossier du Sahara occidental. Les Cahiers de l'Orient 102, 43-57. doi: 10.3917/lcdlo.102.0043

Martin, R., Linstädter, A., Frank, K., and Müller, B. (2016). Livelihood security in face of drought - Assessing the vulnerability of pastoral households. Environ. Modell. Softw. 75, 414-423. doi: 10.1016/j.envsoft.2014.10.012

Martin, S. M., and Lorenzen, K. (2016). Livelihood diversification in Rural Laos. World Develop. 83, 231-243. doi: 10.1016/j.worlddev.2016.01.018

McAllister, R. R. J., Abel, N., Stokes, C. J., and Gordon, L. J. (2006). Australian pastoralists in time and space: the evolution of a complex adaptive system. Ecol. Soc. 11, 41-48

McCarthy, N., and Di Gregorio, M. (2007). Climate variability and flexibility in resource access: the case of pastoral mobility in Northern Kenya. Environ. Develop. Econ. 12, 403-421. doi: 10.1017/S1355770X07003609

McPeak, J. G., Peter, D., and Cheryl, R. D. (2011). Risk and Social Change in an African Rural Economy: Livelihoods in Pastoralist Communities. London: Routledge.

Melketo, T., Schmidt, M., Bonatti, M., Sieber, S., Müller, K., and Lana, M. (2021). Determinants of pastoral household resilience to food insecurity in Afar region, northeast Ethiopia. J. Arid Environ. 188:104454. doi: 10.1016/j.jaridenv.2021.104454

Meuwissen, M. P. M., Feindt, P. H., Speigel, A. L. (2019). A framework to assess the resilience of farming systems. Agricult. Syst. 176:102656. doi: 10.1016/j.agsy.2019.102656

Milestad, R., and Darnhofer, I. (2003). Building farm resilience: The prospects and challenges of organic farming. J. Sustain. Agric. 2, 81-97.

Moritz, M. (2008). Competing paradigms in pastoral development? a perspective from the Far North of Cameroon. World Develop. 36, 2243-2254. doi: 10.1016/j.worlddev.2007.10.015

Narayan, D. (1999). Bonds and bridges: social and poverty. Policy Research Working Paper Series 2167, The World Bank.

Noel, J. (2019). Etude des trajectoires des éleveurs camelins dans la région de Guelmim Oued-Noun au Maroc. Mémoire de fin d'étude, Ecole Supérieure d'Agro-Développement International (ISTOM), CIRAd, ICARDA.

Nori, M. (2019). Herding through uncertainties-principles and practices: exploring the interfaces of pastoralists and uncertainty: results from a literature review, EUI Working Paper RSCAS 2019/68, San Domenico di Fiesole: European University Institute doi: 10.2139/ssrn.3457237

O'Brien, K. L., and Wolf, J. (2010). A values-based approach to vulnerability and adaptation to climate change. Wiley Interdisciplin. Rev. Climate Change 1, 232-242. doi: 10.1002/wcc.30

Perez, C., Jones, E. M., Kristjanson, P., Cramer, L., Thornton, P. K., Förch, W., et al. (2015). How resilient are farming households and communities to a changing climate in Africa? a gender-based perspective. Global Environ. Change 34, 95-107. doi: 10.1016/j.gloenvcha.2015.06.003

Ramos, X., and Solber, J. (2005). On the application of efficiency analysis to the study of the dimensions of human development. Rev. Income Wealth 51, 285-309 doi: 10.1111/j.1475-4991.2005.00155.x

Robert, P., and Lallau, B. (2016). Mesurer la résilience des ménages ruraux sénégalais: une approche en termes de trajectoires et seuils de moyens d'existence. Ethique et économique 13:2.

Rufino, M. C., Quiros, C., Boureima, M., Desta, S., Douxchamps, S., Herrero, M., et al. (2013). Developing Generic Tools for Characterizing Agricultural Systems for Climate and Global Change Studies (IMPACTlite-Phase 2). Nairobi: ILRI.

Sallu, S. M., Twyman, C., and Stringer, L. C. (2010). Resilient or vulnerable livelihoods? assessing livelihood dynamics and trajectories in rural Botswana. Ecol. Soc. 15:403. doi: 10.5751/ES-03505-150403

Sarker, M. N. I., Wu, M., Alam, G. M., and Shouse, R. C. (2020). Livelihood diversification in rural Bangladesh: Patterns and determinants 
in disaster prone riverine islands. Land Use Policy. 20:10470. doi: 10.1016/j.landusepol.2020.104720

Schilling, J., Hertig, E., Tramblay, Y., and Scheffran, J. (2020). Climate change vulnerability, water resources and social implication in North Africa. Reg. Environ. Change. 20:15. doi: 10.1007/s10113-020-0 1597-7

Schreiner, M. (2007). Poverty Probability Index (PPI®) for Morocco. Available online at: www.povertyindex.org/country/morocco

Scoones, I. (1998). Sustainable rural livelihoods: a framework for analysis. IDS Working Paper 72.

Scoones, I. (2009). Livelihoods perspectives and rural development. J. Peasant Stud. 36, 171-196. doi: 10.1080/03066150902820503

Speranza, I. C. (2013). Buffer capacity: capturing a dimension of resilience to climate change in African smallholder agriculture. Reg. Environ. Change 13, 521-535. doi: 10.1007/s10113-012-0391-5

Thébaud, B., and Batterbury, S. (2001). Sahel Pastoralists: opportunism, struggle, conflict and negotiation. Global Environ. Change 11, 69-78. doi: 10.1016/S0959-3780(00)00046-7

Tittonell, P., Vanlauwe, B., Leffelaar, P., Rowe, E. C., and Giller, K. E. (2005).. Exploring diversity in soil fertility management of smallholder farms in western Kenya: I. Heterogeneity at region and farm scale. Agricult. Ecosyst. Environ. 110, 149-165. doi: 10.1016/j.agee.2005. 04.001

van Wijk, M., James, H., Leo, G., Sam, A., Augustine, A., David, B., et al. (2020). The Rural Household Multiple Indicator, S.urvey, data from 13,310 farm households in 21 countries. Scientific Data 7, 1-9. doi: 10.1038/s41597-020-0388-8

Vermeulen, S. J., Dinesh, D., Howden, S. D., Cramer, L., and Thornton, P. K. (2018). Transformation in practice: a review of empirical cases of transformational adaptation in agriculture under climate change. Front. Sustain. Food Syst. 15:65. doi: 10.3389/fsufs.2018. 00065

Vincent-Ponroy, J., and Chevalier, F. (2018). Les récits de vie. In: Françoise Chevalier éd., Les méthodes de recherche du DBA (pp. 158-175).
Caen, France: EMS Editions. Available online at: https://www.cairn. info/les-methodes-de-recherche-du-dba-9782376871798-page-158.htm doi: 10.3917/ems.cheva.2018.01.0158 (accessed 17/07/2019).

Walker, B., Holling, C. S., Carpenter, S. R., and Kinzig, A. (2004). Resilience, adaptability and transformability in social-ecological systems. Ecol. Soc. 9, 1-5. doi: 10.5751/ES-00650-090205

Ward, J. H. (1963). Hierarchical grouping to optimize an objective function. J. Am. Statistic. Assoc. 58, 236-244.

World Bank. (2017). Living Standards Measurement Survey. Available online at: www.worldbank.org/lsms. (accessed 15 Jan 2017).

Wu, N., Ismail, M., Joshi, S., Yi, S. L., Shrestha, R. M., and Jasra, A. W. (2014). Livelihood diversification as an adaptation approach to change in the pastoral Hindu-Kush Himalayan region. J. Mt. Sci. 11, 1342-1355. doi: $10.1007 / \mathrm{s} 11629-014-3038-9$

Conflict of Interest: The authors declare that the research was conducted in the absence of any commercial or financial relationships that could be construed as a potential conflict of interest.

Publisher's Note: All claims expressed in this article are solely those of the authors and do not necessarily represent those of their affiliated organizations, or those of the publisher, the editors and the reviewers. Any product that may be evaluated in this article, or claim that may be made by its manufacturer, is not guaranteed or endorsed by the publisher.

Copyright (c) 2022 Alary, Caulfield, Amsidder, Juanes, Boujenane, Sraïri, Sam, Hammond and Van Wijk. This is an open-access article distributed under the terms of the Creative Commons Attribution License (CC BY). The use, distribution or reproduction in other forums is permitted, provided the original author(s) and the copyright owner(s) are credited and that the original publication in this journal is cited, in accordance with accepted academic practice. No use, distribution or reproduction is permitted which does not comply with these terms. 